\title{
DZIAtANIA KRYMSKOTATARSKIEGO RUCHU NARODOWOWYZWOLEŃCZEGO W WARUNKACH ANEKSJI KRYMU (na przykładzie blokady pótwyspu)
}

\author{
THE ACTIONS OF CRIMEAN TATARS NATIONAL \\ LIBERATION MOVEMENT UNDER CONDITIONS \\ OF ANNEXATION OF THE CRIMEA \\ (example of Crimea blockade)
}

\begin{abstract}
In 2015, due to the rapidly changing political and economic situation in the world, the issue of annexation of the Crimea gave way to such news as the political situation in Syria and Russia's participation in hostilities in this country, the imposition of sanctions on Russia and their impact on the Russian economy, falling oil prices and its effects, the situation with refugees in the European Union. To draw attention to the problem of the annexation of the Crimea and Crimean Tatars, Mejlis and its chairman Refat Chubarov and political leader of the Crimean Tatars Mustafa Dzhemilev initiated a peace action of blockade of Crimea. Blockade had two stages-transportation and food blockade and energy blockade. The action ended early in 2016. Crimean Tatars failed to achieve their main goal, release of all political prisoners, yet the blockade showed deep dependence of the peninsula from Ukraine's economy.
\end{abstract}

Key words: Crimean Tatars National Liberation Movement; occupation; peninsula; Crimea; naval blockade; food transport blockade; energy blockade
OKSANA VOYTYUK

Uniwersytet w Białymstoku, Białystok E-mail: oksana.voytyuk@gmail.com This work was supported by the author's own resources.

No competing interests have been declared.

This is an Open Access article distributed under the terms of the Creative Commons Attribution 3.0 PL License (creativecommons.org/licenses/by/3.0/pl/), which permits redistribution, commercial and non-commercial, provided that the article is properly cited. (C) The Author(s) 2016.

Publisher: Institute of Slavic Studies, Polish Academy of Sciences [Wydawca: Instytut Slawistyki PAN] 
W 2015 roku, w związku z dynamicznie zmieniającą się sytuacją polityczną i gospodarczą na świecie, kwestia aneksji Krymu ustąpiła miejsca takim wiadomościom jak sytuacja w Syrii i udział Rosji w działaniach wojennych na terenie tego kraju, nałożenie sankcji na Rosję oraz ich wpływ na rosyjską gospodarkę, spadek cen ropy naftowej i jego skutki, sytuacja z uchodźcami w Unii Europejskiej. Celem zwrócenia uwagi na aneksję Krymu i problem Tatarów krymskich, Medżlis z siedzibą w Kijowie z przewodniczącym Refatem Czubarowem i politycznym przywódcą Tatarów krymskich Mustafą Dżemilewem inicjowali bezterminową pokojową akcję blokady Krymu. Blokada miała dwa etapy transportowo-towarowa i energetyczna. Akcja zakończyła się na początku 2016 roku. Bez względu na to, że nie udało się osiągnąć głównego celu - uwolnienia więźniów politycznych, blokada pokazała wysoki stopień zależności półwyspu od gospodarki Ukrainy.

Słowa kluczowe: Krymskotatarski Ruch Narodowo-Wyzwoleńczy; okupacja; półwysep; Krym; blokada morska; blokada energetyczna; blokada towarowo-transportowa

W 2015 roku, w związku z dynamicznie zmieniającą się sytuacją polityczną i gospodarczą na świecie, kwestia aneksji Krymu ustąpiła miejsca takim wiadomościom jak sytuacja w Syrii i udział Rosji w działaniach wojennych na terenie tego kraju, nałożenie sankcji na Rosję oraz ich wpływ na rosyjską gospodarkę, spadek cen ropy naftowej i jego skutki, sytuacja z uchodźcami w Unii Europejskiej. Celem zwrócenia uwagi na aneksję Krymu i problem Tatarów krymskich, Medżlis z siedzibą w Kijowie, z przewodniczącym Refatem Czubarowem i politycznym przywódcą Tatarów krymskich Mustafą Dżemilewem, zainicjowali bezterminową pokojową akcję blokady Krymu. Do akcji włączył się Prawy Sektor i Cywilny Korpus „Azow” („Азов присоединился к блокаде Крыма", 2015), a także aktywiści batalionu "Ajdar”, batalionu MSW „Cherson”, Państwowa Straż Graniczna oraz Służba Bezpieczeństwa Ukrainy (SBU). W planach Tatarów krymskich i działaczy ukraińskich blokada Krymu miała składać się z kilku etapów:

I - blokada transportowa i towarowa;

II - blokada energetyczna;

III - blokada morska.

Cechą charakterystyczną tej akcji było to, iż miała ona wyznaczoną datę tylko pierwszego etapu, drugi etap rozpoczął się spontanicznie, a do realizacji trzeciego etapu nie doszło.

\section{BLOKADA TRANSPORTOWO-TOWAROWA}

Transportowa i towarowa blokada Krymu rozpoczęła się 20 września 2015 roku o godzinie 12.00 w obwodzie Chersońskim na granicy administracyjnej z Krymem po ukraińskiej stronie. Celem było blokowanie ciężarówek z towarami w kierunku Krymu na przejściach Czongar, Czapłynka i Kałanczak (Ryc. 1), aby pokazać zależność półwyspu od Ukrainy. Początkowo akcja miała trwać dopóty, dopóki władze na Kremlu nie spełnią wymagań, które wystosowali uczestnicy blokady. Główne wymagania Tatarów krymskich i ukraińskich aktywistów były następujące: 
- deokupacja Krymu i przywrócenie terytorialnej integralności Ukrainy („Перекриті дороги та довжелезні черги з фур. Як почалася блокада Криму", 2015);

- skuteczna ochrona praw i wolności obywateli Ukrainy zamieszkujących na terytorium czasowo okupowanym;

- natychmiastowe zaprzestanie represji i dyskryminacji wobec ukraińskich obywatelimieszkańców Krymu, działaczy krymskotatarskiego ruchu narodowego, członków Medżlisu i samorządu Tatarów krymskich;

- natychmiastowe uwolnienie więźniów politycznych: Ahtema Czyjgoza Ali Asanowa, Rustema Waitowa, Mustafy Degermendży, Ruslana Zejtullajewa, Aleksandra Kol'czenko, Nuri Primowa, Feraty Sajfullajewej, Nadiji Sawczenko i Olega Sencowa;

- umorzenie sfabrykowanych spraw kryminalnych na tle politycznym wobec Tatarów krymskich i innych narodowości na Krymie;

- wolność krymskotatarskich i ukraińskich mediów na Krymie;

- pozwolenie na wjazd liderom Medżlisu Tatarów krymskich i umorzenie wobec nich spraw kryminalnych oraz pozwolenie na wjazd innym działaczom społecznym krymskotatarskiego ruchu narodowego, Ismetowi Jukselowi oraz Sinawerowi Kadyrowowi;

- zapewnienie warunków dla stałej obecności na terytorium czasowo okupowanym międzynarodowych misji, w szczególności misji ONZ ( Чубаров подробно огласил причины и цели блокады Крыма”, 2015; „Джемилев: Будем менять товары для Крыма на наших заключенных", 2015; „Семь вопросов и ответов о блокаде Крыма”, 2015).

Blokada Krymu miała także na celu przywrócenie uwagi społeczności międzynarodowej na naruszanie praw człowieka, ale także miała wywrzeć nacisk na gospodarkę półwyspu. Poza tym, w komunikacie opublikowanym przez sztab akcji blokady Krymu apelowano do ukraińskich władz, aby zlikwidowały uchwałę O strefie wolnego handlu "Krym". Według stanu na 25 stycznia 2016 roku w Radzie Najwyższej Ukrainy został zarejestrowany projekt uchwały O likwidacji strefy wolnego handlu "Krym” (inicjatorem był O. Gonczarenko z Bloku P. Poroszenki), jednak tekst projektu nie jest dostępny na internetowej stronie Parlamentu Ukrainy i nie doszło do uchwały („У Раді зареєстрували законопроект про скасування вільної економічної зони “Крим»", 2015).

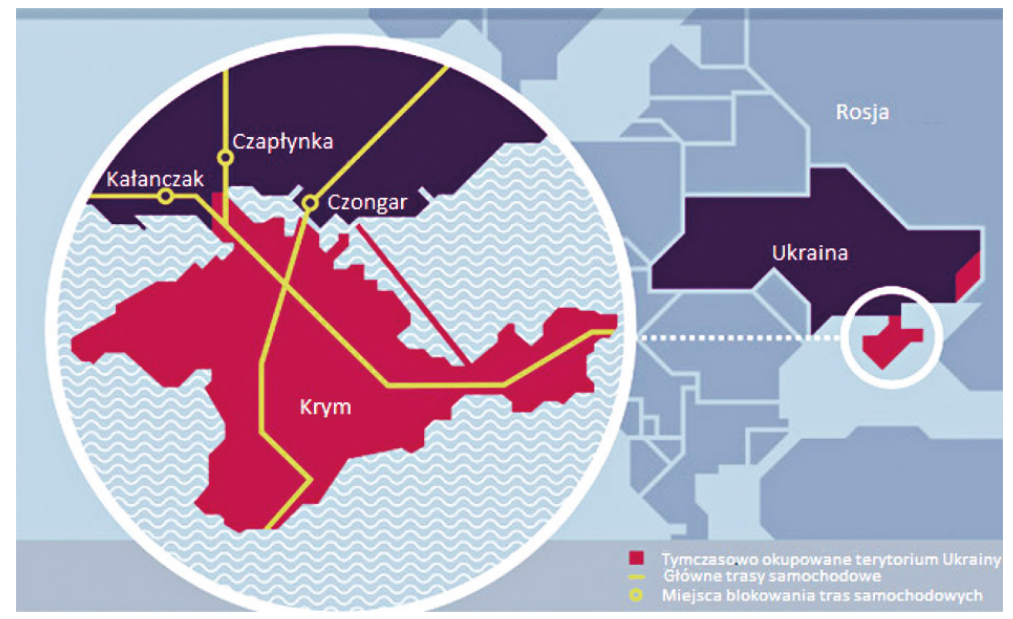

Ryc. 1.

Źr ó dło: „Опубликована инфографика следствий блокады Крыма” (2015). 
W pierwszym dniu blokady transportowo-towarowej zatrzymano 240 ciężarówek, a ilość zablokowanych towarów wyniosła 3,5 tys. ton. Krym w 80\% zależy od dostaw żywności z Ukrainy. Sytuację dostaw żywności jeszcze bardziej skomplikowało wydanie uchwały przez Gabinet Ministrów Ukrainy w dniu 16 grudnia 2015 roku O ograniczeniu dostaw poszczególnych towarów (prac, usług) z czasowo okupowanego terytorium Ukrainy na inne terytorium Ukrainy i z innego terytorium Ukrainy na czasowo okupowane terytoria. Na liście zabronionych towarów znalazła się żywność, która między innymi stanowi tzw. „koszyk spożywczy” („Про обмеження поставок окремих товарів (робіт, послуг) з тимчасово окупованої території на іншу територію України та/або з іншої території України на тимчасово окуповану територію", 2015).

Należy uznać, iż w świetle ostatnich wydarzeń kwestia Krymu z wiadomości pierwszej wagi zeszła na drugi-trzeci plan, o Krymie zaczęto zapominać i mówić o jego sytuacji jako nieodwracalnej. Jednak blokada transportowa i towarowa nagłośniła problem nie tylko społeczeństwu ukraińskiemu (przy okazji wskazując na objawy korupcji i wzbogacenia się tych, którzy dostarczają żywność i inne towary na Krym), ale także wspólnocie międzynarodowej, iż Krym to Ukraina.

Dzięki działaniom Medżlisu i Tatarów krymskich zamieszkujących w kontynentalnej Ukrainie, blokada Krymu stała się akcją ogólnoukraińską oraz sprawiła, iż Tatarzy krymscy stali się pełnoprawnymi uczestnikami procesu negocjacyjnego w kwestiach Krymu i sytuacji swoich rodaków na półwyspie („Чубаров: Блокада полуострова возвращает проблему Крыма в первый ряд", 2015).

Wokół zasadności blokady było sporo spekulacji w społeczeństwie ukraińskim, opinie były podzielone. W wywiadzie przeprowadzonym przez Aljazeere niektórzy mieszkańcy regionów przygranicznych Krymu uważali, iż ta akcja rozpoczęła się za późno, ale mimo wszystko wspierali działania Tatarów krymskich i aktywistów; były także osoby, którym trudno było powiedzieć czy te działania były potrzebne. Natomiast Anton Shekhovtsov w artykule The Crimean blockade: how Ukraine is losing Crimea for the third time dla Open Democracy pisze, że aneksja Krymu przez Rosję to nie jest pierwsza utrata Krymu przez Ukrainę i nie warto było podejmować tego typu działań, gdyż mogą przynieść negatywne skutki dla Ukrainy (Stewart, 2015). Ogólnie biorąc, około 50\% Ukraińców wspierało tę akcję, a 25\% było przeciwnych (Ryc. 2) („Половина українців схвалили блокаду Криму активістами, третина - проти", 2016).
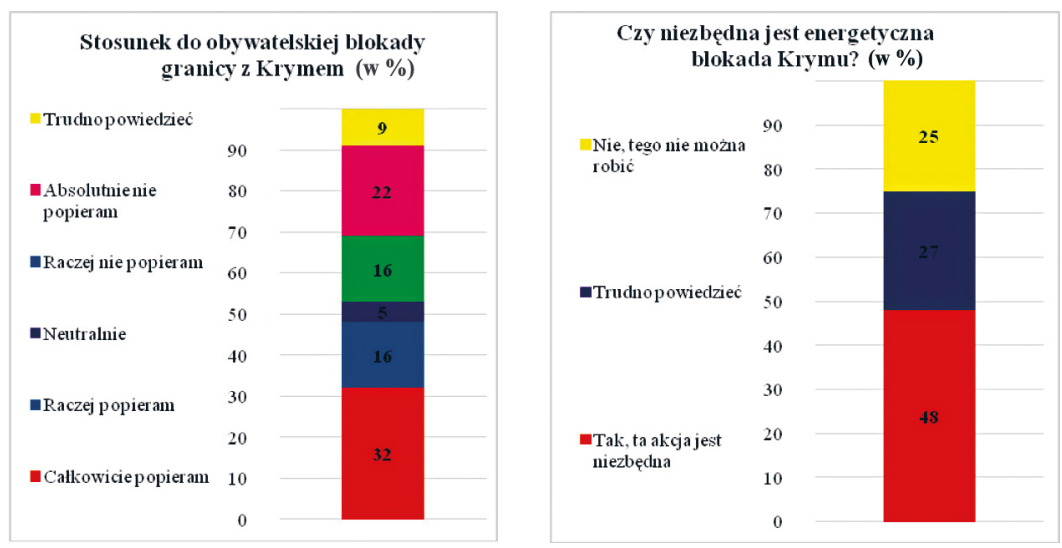

Ryc. 2.

Źr ó dło: „48\% українців вважають, що потрібно проводити енергетичну блокаду Криму” (2016). 
Doradca ministra ds. polityki rolnej i żywności Aleksander Liew także nie popierał blokady, ponieważ uważał, że jest ona sprzeczna z prawem i jest nieskuteczna, gdyż został wybrany niewłaściwy okres - jesień. Gdyby tej akcji dokonano wiosną, skutki jej byłyby bardziej odczuwalne. Poza tym A. Liew uważat, że w Rosji ta akcja jest postrzegana jako odrzucenie terytorium Ukrainy („Украина отторгает Крым. Сама”, 2015). Politolog Wiktor Mironienko uważa, że trudno uzyskać o tej akcji obiektywną informację, gdyż Tatarzy krymscy są i po krymskiej stronie, i to oni we wszystkich kłopotach i problemach oskarżają Ukrainę, Medżlis i ukraiński rząd. Natomiast zastępca dyrektora kanału telewizyjnego ATR (zakazanego na Krymie) Ajder Mużdaba, uważa, że tak wypowiada się grupa Tatarów krymskich, która zgodziła się na współpracę w władzami rosyjskimi i tym samym zdradziła pamięć historyczną i narodową narodu krymskotatarskiego. Jednak jest to bardzo nieliczna grupa. Także A. Mużdaba twierdzi, iż

dzisiaj publiczną opinię Tatarów krymskich z Krymu usłyszeć bardzo trudno, gdyż po każdej wypowiedzi, a nawet po "like" w Facebooku, do domu przychodzi policja. Dlatego ludzie boja się rozmawiać nie tylko z dziennikarzami, a nawet najbliższą rodziną i krewnymi, w ogóle boją się mówić. W rzeczywistości, jeśli brać pod uwagę prawdziwy nastrój Tatarów krymskich, czują się porzuceni i zapomniani przez Ukrainę i społeczność międzynarodową. Ludzie popierają te działania, ponieważ wierzą, że blokada przyczyni się do aktualizacji problematyki represji na Krymie, może to nieco ułatwi ich sytuację („, Крымская блокада: Итоги первой недели”, 2015).

Rozpoczęcie blokady transportowej i towarowej Krymu jej uczestnicy uzasadniali następującymi przyczynami:

Po pierwsze, rozpoczęła się ona w przededniu wystąpienia W. Putina na sesji Zgromadzenia ONZ z propozycją nowego światowego porządku;

Po drugie, kwestia Krymu potrzebuje ciągłego nagłośnienia i uwagi;

Po trzecie, w okresie jesienno- zimowym, w Cieśninie Kerczeńskiej są sztormy, które uniemożliwiają nawigację, poza tym przy bardzo niskich temperaturach Cieśnina zamarza, promy nie kursują, co zwiększa zależność energetyczną i żywnościową Krymu od Ukrainy.

Po aneksji Krymu w marcu 2014 roku, blokada półwyspu stała się pierwszym systemowym działaniem z ukraińskiej strony. Udało się tego dokonać dzięki stanowczości, determinacji i wysitkom działaczy krymskotatarskiego ruchu narodowego oraz udziałowi ukraińskich aktywistów. Od czasu przerwania połączeń kolejowych oraz zakrycia Północnokrymskiego kanału blokada stała się jednym z największych działań w kierunku wywierania wpływu na nowe władze krymskie („Крымская блокада: Итоги первой недели", 2015).

Cechą charakterystyczną blokady było to, iż o podjęciu działań dotyczących blokady Krymu ogłosiły nie władze ukraińskie, a liderzy Medżlisu i krymskotatarskiego ruchu narodowo-wyzwoleńczego, a więc ryzyko akcji ponosił Medżlis i Prawy sektor (Сергеева, 2015). Blokada miała wyłącznie obywatelski status. Faktycznie pozycję Ukrainy w tej kwestii wyrazili aktywiści i działacze organizacji społecznych i pozarządowych. Blokada żywnościowa pokazała, iż nawet niewielka grupa działaczy społecznych jest w stanie obnażyć problem korupcji i nielegalnego biznesu w warunkach okupacji Krymu. Potwierdzeniem tego jest także „Krymski Tytan”, fabryka produkcji tlenku tytanu, która należy do jednego z najbogatszych oligarchów Ukrainy Dmytra Firtasza. Jak informuje portal BlackSeaNews, bez względu na okupację i blokadę Krymu, do fabryki są dostarczane ukraińskie surowce (ilmenit) drogą okrężną - z Irszańskiego zakładu górnictwa i przetwórstwa, usytuowanego w obwodzie Żytomyrs'kim, ilmenit drogą kolejową transportuje się do Charkowa, stąd do rosyjskiego portu nad Morzem Czarnym - Noworosyjska, a dalej drogą morską do okupo- 
wanego Krymu („Украина продолжает снабжать сырьем завод «Титан» в оккупированном Крыму", 2015). Blokada transportowa i towarowa dotknęła nie tylko Krym, ale również południowe regiony Ukrainy - Chersoński, Mykołajiws'ki, Zaporiżski, które z półwyspem są połączone ścisłymi więziami gospodarczymi.

Już od pierwszych dni blokada Krymu wywoływała niezadowolenie władz rosyjskich, które zadeklarowały, iż będą podnosić tę kwestię w organizacjach międzynarodowych („Россия намерена поднимать вопрос блокады Крыма в международных организациях", 2015), Także rosyjskie media zaczęły dyskredytować blokadę poprzez podawanie informacji niezgodnych z rzeczywistością. Na przykład, w pierwszych dniach blokady rosyjskie media poinformowały o rzekomym przekroczeniu administracyjnej granicy z Krymem ciężarówek. Natomiast strona ukraińska natychmiast wydała orzeczenie, iż informacje o domniemanym zatrzymaniu ukraińskich dwóch ciężarówek z alkoholem nie odpowiadają rzeczywistości („Российские спецслужбы пытаются дискредитировать блокаду Крыма - Госпогранслужба Украины", 2015). Tymczasem rosyjscy prokuratorzy Krymu wraz z lokalnym Ministerstwem informacji wydali zalecenie, aby media regionalne nie używały słowa "Medżlis" w swoich publikacjach. W odpowiedzi na cywilną blokadę Krymu zorganizowaną przez Medżlis Tatarów krymskich, krymskie władze nie wykluczają zakazu działalności krymskotatarskiego organu przedstawicielskiego na terytorium Rosji, jak i na Krymie. W komentarzu dla agencji prasowej TASS wicepremier republiki, Ruslan Belbek, porównał Medżlis do zakazanej w Federacji Rosyjskiej organizacji „Prawy Sektor":

Organizacja Czubarowa i Dżemilewa tak samo jak Prawy Sektor prowadzi antynarodową i destrukcyjną działalność, nazywając liderów Medżlisu pasożytami, którzy pod hasłami patriotyzmu niszczą własne państwo i stanowią zagrożenie dla otoczenia. Jeśli ci działacze nadal będą prowadzić działalność ekstremistyczną i będą wspótpracować z zakazanymi w Rosji organizacjami, to Medżlis i jego działalność zostaną zakazane w Rosji („Месть за блокаду. Меджлис в Крыму приравнивают к «Правому сектору»", 2015).

Jak twierdzi Lenur Isliamow, właściel krymskotatarskiego kanału ATR, Rosjanie próbowali negocjować w sprawie zniesienia blokady i nawet zgodzili się wykonać jeden z wymogów blokady - uwolnienie więźniów politycznych, w zamian na uwolnienie rosyjskich jeńców wojennych. Jednak komitet organizacyjny blokady w imieniu uczestników akcji na taką propozycję nie przystał, wyjaśniając, że „nie zamierza wymieniać patriotów na terrorystów". A jeśli będą wymieniać, to na konwoje humanitarne, które będą wjeżdżać na terytorium Krymu pod ukraińską flagą. Jeśli Rosja zgodzi się na taką wymianę, Ukraina wyśle tyle żywności, ile będzie potrzeba („Крымская блокада: Итоги первой недели”, 2015).

\section{BLOKADA ENERGETYCZNA}

Na początku października dokonano szeregu aktów dywersyjnych -- uszkodzone zostaty słupy trakcji elektrycznej, która dostarcza prąd na Krym („На Херсонщині пошкодили опору ЛЕП, що постачає електрику в Крим", 2016). Były to akty dywersyjne, jednak sprawców nie udało się znaleźć, toteż strony rosyjska i ukraińska wymieniły się wzajemnymi oskarżeniami, Rosjanie obarczają winą Medżlis i Prawy Sektor, strona ukraińska - rosyjskich dywersantów („Чубаров: «Энергетическая блокада» Крыма может начаться в октябре", 2015). 
Przerwy w dostawach prądu na Krym rozpoczęły się na początku października, jednak do całkowitej blokady energetycznej doszło 20 listopada 2015 roku, kiedy powtórnie zostały uszkodzone dwie instalacje elektryczne. W wyniku dywersji wszystkie cztery źródła przesyłowe prądu na Krym zostały odłączone, co spowodowało całkowite odcięcie półwyspu od dostaw energii elektrycznej z Ukrainy. Na Krymie został wprowadzony stan wyjątkowy, gospodarstwa domowe dostawały prąd i wodę w określonych godzinach („В Криму ввели надзвичайний стан", 2015).

Dostawy energii elektrycznej na Krym z Ukrainy zostały wznowione 8 grudnia 2015 roku za pomocą jednej z czterech linii elektrycznych dostarczających prąd na Krym („По всьому Криму відновили енергопостачання", 2015). W tym samym dniu Prawy Sektor ogłosił o zakończeniu swojego udziału w akcji pokojowej blokady Krymu. Uzasadnieniem tej decyzji była zgoda Medżlisu na częściowe wznowienie dostaw prądu na Krym („Правий сектор припиняє участь у торгівельній та енергетичній блокаді Криму”, 2015). "Wznowienie dostaw energii elektrycznej za pomocą jednej z linii jest traktowane jako nowy antyukraiński krok obecnego reżimu i zagrywanie z naszymi wrogami ze strony niektórych naszych partnerów i sojuszników" - powiedział w swoim oświadczeniu Prawy Sektor („Відключити, щоб дати. „Дивна” блокада Криму”, 2015).

Rosja, aby normalizować sytuację na półwyspie, uruchomiła tzw. most energetyczny Kubań-Krym, za pomocą pierwszej linii elektrycznej, położonej na dnie Cieśniny Kerczeńskiej, o mocy 200 megawatów, rozpoczęto dostawy prądu na Krym w dniu 2 grudnia 2015 roku, jednak po kilku dniach doszło do przeciążenia linii i dostawy prądu znów zostaty przerwane („Путін зізнався, що „увімкнув” Крим не дуже вдало”, 2016). W dniu 15 grudnia 2015 roku uruchomiono drugą linię mostu energetycznego (Ryc. 3), dzięki czemu udało się wznowić połączenia trolejbusowe w Symferopolu i Sewastopolu, jednak tych mocy wciąż brakuje i na Krymie dalej obowiązują wahadłowe odłączenia energii elektrycznеј („Крым будет зависеть от украинской электроэнергии минимум до 2018 года”, 2015). Ogólna moc dwóch linii położonych na dnie Cieśniny Kerczeńskiej wynosi 400 megawatów. Jak zapowiadają krymskie władze, taka sytuacja na półwyspie potrwa najprawdopodobniej aż do 2018 roku, zanim na Krymie nie zostaną zbudowane elektrownie w Sewastopolu i Symferopolu o mocy 940 megawatów („Крим буде потерпати від перебоїв з електроенергією до 2018 року - Аксьонов", 2015).

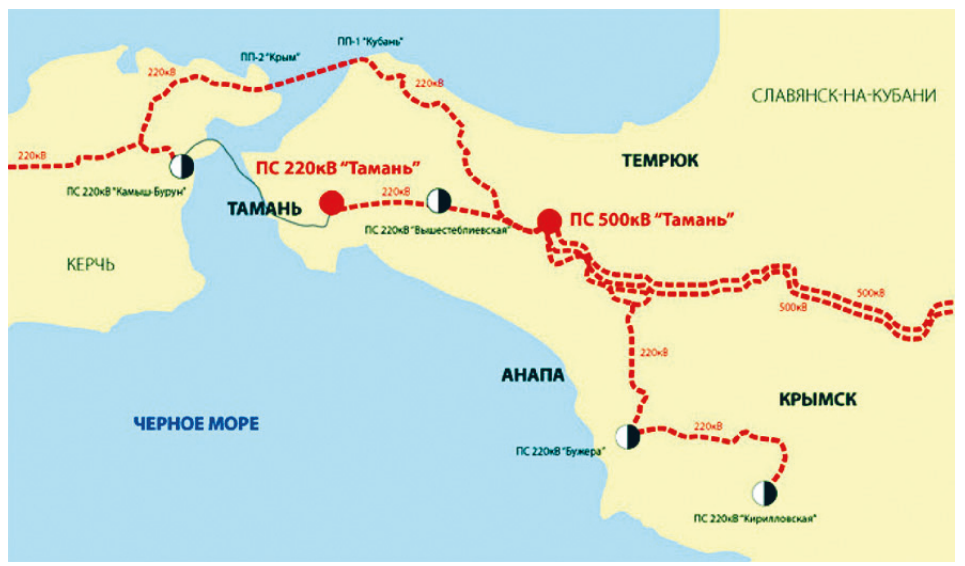

Ryc. 3.

Źródło: „Крим на підсосі: чому енергоміст Кубань - Крим не розв'яже проблем півострова" (2015). 
Głównym celem blokady energetycznej było nie tyle sprawić problemy mieszkańcom okupowanego półwyspu, ile pokazać krymskiemu społeczeństwu i całemu światu zależność energetyczną Krymu od Ukrainy. Blokada energetyczna półwyspu udowodniła, że Rosja nie w pełni kontroluje sytuację gospodarczą na Krymie, co jest sprzeczne z Konwencją genewską z dnia 12 sierpnia 1949 roku O ochronie osób cywilnych podczas wojny. Zgodnie z art. 55 Konwencji,

mocarstwo okupacyjne ma obowiązek zapewniania w miarę wszystkich swoich możliwości zaopatrzenia ludności w żywność i środki lecznicze; powinno ono zwłaszcza sprowadzać żywność, zapasy lecznicze i wszelkie inne konieczne artykuły, jeżeli zasoby terytorium okupowanego są niedostateczn („Konwencja genewska o ochronie osób cywilnych podczas wojny", b.d.).

Rosja nie jest w stanie zagwarantować nieprzerwanej dostawy żywności i energii elektrycznej. Aby uniezależnić się od Ukrainy, niezbędna jest budowa nowych i modernizacja starych linii wysokiego napięcia oraz dwóch elektrociepłowni (Ryc. 4).

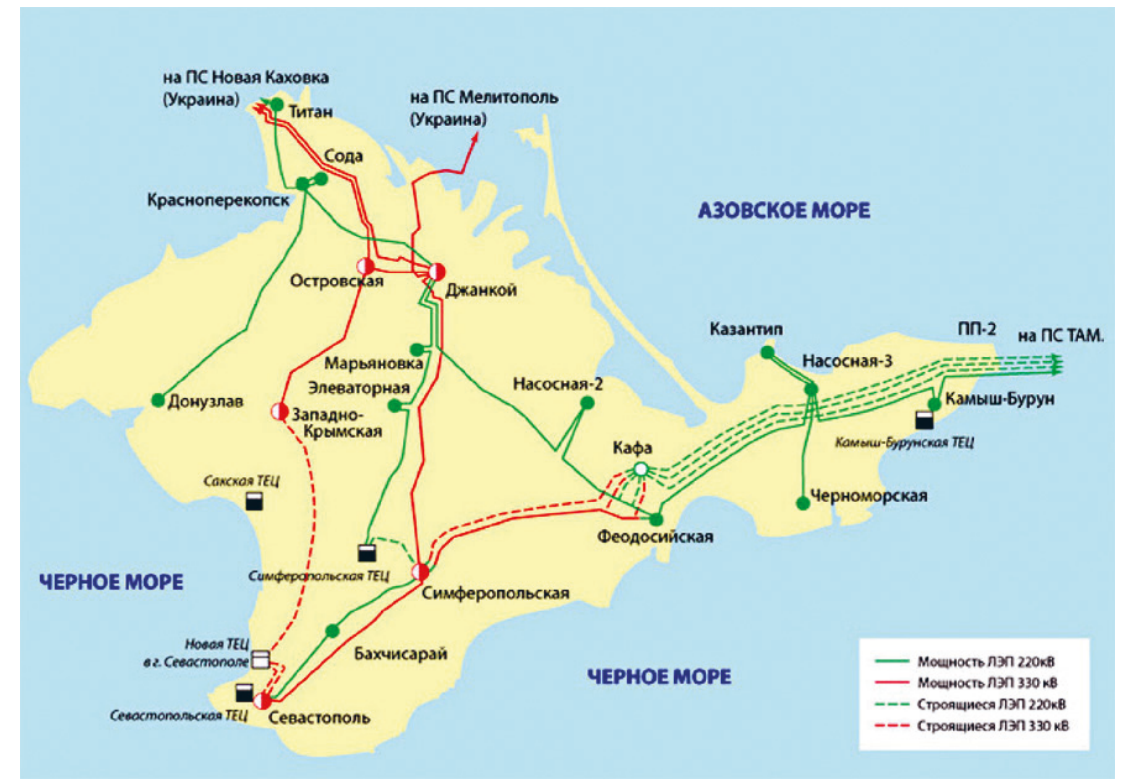

Ryc. 4.

Źr ó d † o: „Крим на підсосі: чому енергоміст Кубань - Крим не розв'яже проблем півострова” (2015).

W rzeczywistości energetyczna blokada Krymu była bardzo ryzykownym krokiem, gdyż Rosja mogła wstrzymać dostawy gazu do Ukrainy („Мустафа Джемилев: Коренной народ Крыма - организованная сила, казывающая сопротивление оккупации в общенациональном масштабе", 2015). Jednak, jak wskazują dane statystyczne, nawet gdyby doszło do wstrzymania przez Rosje dostaw gazu, Ukraina poradziłaby sobie poprzez zwiększenie importu z Unii Europejskiej (Ryc 5). Jak widać z wykresu, w latach 2008-2014 Ukraina znacząco zmniejszyła import gazu ziemnego z Rosji z 52,6 mld $\mathrm{m}^{3}$ rocznie (2008) do 14,5 mld m³ (2014). W 2015 roku import gazu z Unii Europejskiej wynosił 61\%, a z Rosji 39\% („Дві третини газу в Україну надходить з ЄС, і лише третина - з Росії”, 2015). W 2015 
roku import gazu ziemnego wynosit $16,4 \mathrm{mld}^{3}$ rocznie, z czego import z UE stanowił 10,3 mld m³ rocznie (ze Słowacji - 9,7 mld m³, Węgier - 0,5 mld m³, Polski - 0,1 mld m³). Import gazu z Rosji w 2015 roku wynióst jedynie 6,1 mld m³ („Україна скоротила імпорт газу у 2015 році на $16 \% ", 2016)$.

IMPORT GAZU ZIEMNEGO DO UKRAINY (W MLD M ROCZNIE)

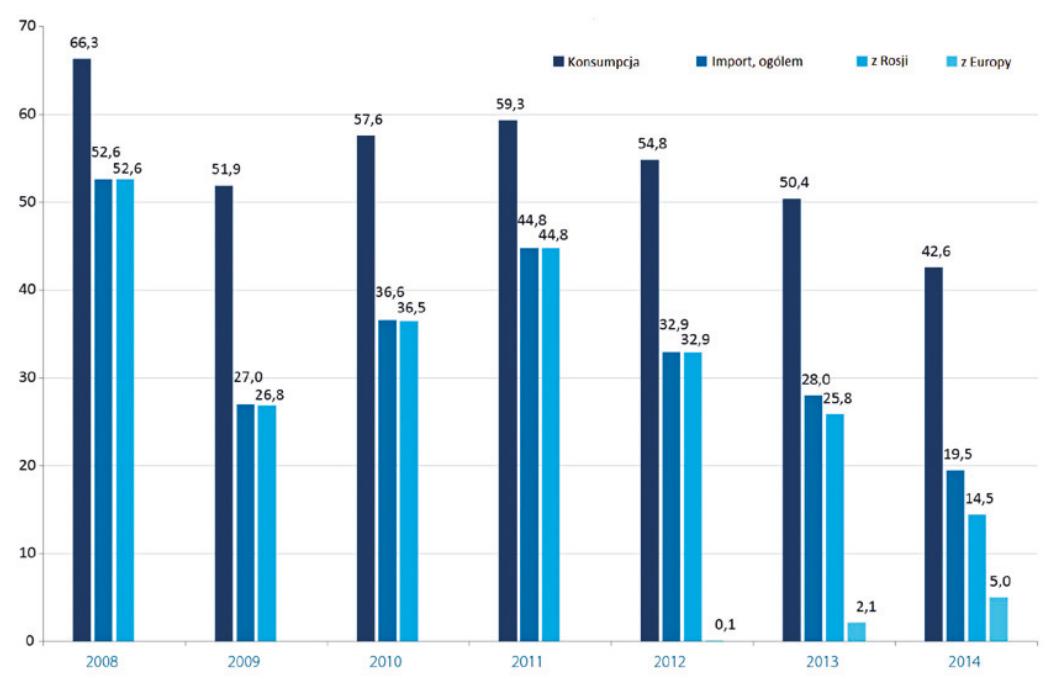

Ryc. 5.

Źr ó d † о: „Iмпорт природного газу в Україну у 2008-2014рр.” (2016).

W 2016 roku Ukraina planuje całkowicie zrezygnować z rosyjskiego gazu i importować go wyłącznie z Unii Europejskiej („,Нафтогаз припускає повну відмову від газу Газпрому з 2016", 2015). W razie wzrostu napięcia na linii Kijów-Moskwa, ewentualne wstrzymanie dostaw rosyjskiego gazu w celu wywarcia nacisku nie wniesie poważnych zmian funkcjonowania ukraińskiej gospodarki. Jednak to nie oznacza, iż Ukraina nie zależy energetycznie od Rosji, są jeszcze dostawy energii elektrycznej, węgla i paliwa jądrowego dla ukraińskich elektrowni atomowych, od dostaw których Ukraina wciąż zależy („Потрійна енергетична залежність України", 2014). Poza tym wraz z rozpoczęciem energetycznej blokady Krymu, Rosja zaczęła ściągać do administracyjnej granicy z Ukrainą czołgi i wyrzutnie rakietowe "Grad” W kierunku Czapłynki, Kałanczaka i Czongara („Росія розмістила танки та „Гради" біля лінії розмежування між Кримом і Херсонщиною через підрив ЛЕП - Ківа", 2015). Skupienie techniki wojskowej na granicy z Ukrainą ze strony Krymu obnażyło, jak wygląda bezpieczeństwo ukraińskich granic w warunkach wojny na wschodzie i okupacji Krymu. Dla zapewnienia bezpieczeństwa granic planowano (inicjatywa M. Dżemilewa) stworzenie krymskotatarskiego batalionu „Krym”, jednak dotychczas nie został on sformowany, a administracyjna granica z Krymem wciąż jest zagrożona (Самар, 2015a).

Jeśli transportowa i towarowa blokada Krymu rozpoczęła się zgodnie z harmonogramem, to blokada energetyczna rozpoczęła się spontanicznie, gdyż była spowodowana 
wysadzeniem instalacji elektrycznych, zresztą zakończyła się ona tak samo, nie osiągając postawionego celu - uwolnienia wszystkich więźniów politycznych na Krymie (Самаp, 2015b).

Blokada Krymu stała się drugim znaczącym krokiem na drodze wykorzystania metod wojny ekonomicznej wobec państwa-agresora. Pierwszym takim przedsięwzięciem było ograniczenie dostaw wody pitnej na półwysep za pomocą Północnokrymskiego kanału wiosną 2014 roku. Energetyczna blokada Krymu bez wątpienia zaskoczyła okupacyjny rząd, ponieważ znacznie dotknęła rosyjski budżet i mocno uderzyła w już niezbyt pozytywny wizerunek Rosji (Самар, 2015b).

Blokada energetyczna, podobnie jak wznowienie dostaw energii elektrycznej, wywołały sporo pytań i spekulacji na ten temat. Prezydentowi Ukrainy P. Poroszence udało się przekonać inicjatorów blokady i jej uczestników do wznowienia dostaw energii elektrycznej, bez wykonania podstawowego wymogu (uwolnienia więźniów politycznych). Argumentowano następująco:

- nacisk Zachodu na kierownictwo państwa;

- potrzeba zapewnienia energii elektrycznej dla niektórych rejonów obwodu Chersońskiego, które zostały bez prądu w wyniku dywersji;

- zagrożenie katastrofą, do której mogłoby dojść w razie dłuższego wstrzymania prądu fabryce tlenku tytanu "Krymski Tytan” (jednak dowodów na wzrost zagrożenia uczestnicy blokady nie znaleźli) („Джемілєв назвав причини відновлення Україною електропостачання в Криму", 2015). W 2015 roku fabryka zmieniła nazwę na Ukrainian Chemical Products (Путілов, 2015);

- troska o mieszkańców Krymu, gdyż ograniczenia dostaw energii elektrycznej najbardziej dotknęły gospodarstwa domowe oraz szpitale, szkoły, przedszkola, Rosjanie bowiem przede wszystkim zapewniali prąd dla wojska, Federalnej Służby Bezpieczeństwa (FSB), a w ostatniej kolejności dla mieszkańców („Джемілєв назвав причини відновлення Україною електропостачання в Криму", 2015);

- 31 grudnia 2015 roku skończył się kontrakt na dostawy energii elektrycznej na Krym i Ukraina, aby wywiązać się z obowiązków i uniknąć oskarżeń ze strony rosyjskiej o naruszenie warunków kontraktu, wznowiła dostawy energii elektrycznej na dwa tygodnie, które pozostały do końca roku („Джемілєв назвав причини відновлення Україною електропостачання в Криму", 2015).

Koordynator akcji blokady Krymu Lenur Isliamow powiedział, iż aktywiści będą metodami politycznymi domagać się zakazu dostaw energii elektrycznej na Krym („Іслямов пояснив ослаблення енергоблокади Криму тиском Заходу", 2015).

Z początkiem 2016 roku dostawy prądu na Krym zostały wstrzymane ze względu na niepodpisanie nowego porozumienia z Rosją. Nowe porozumienie, jeżeli zostanie ono zawarte, powinno precyzyjnie wskazywać, iż „energię elektryczną Ukraina dostarcza na czasowo okupowane przez Federację Rosyjską terytorium Autonomicznej Republiki Krym" ( „Джемілєв: Питання з контрактом на постачання електроенергії в Крим закрите”, 2016). Poza tym, jak powiedział lider Tatarów krymskich M. Dżemilew, kontrakt ma być podpisany na szczeblu ministerialnym oraz pod warunkiem uwolnienia więźniów politycznych, zaprzestania wszelkich prześladowań i poszukiwania wszystkich zaginionych, uprowadzonych aktywnych działaczy krymskotatarskiego ruchu narodowego, zagwarantowania wolności demokratycznych („Джемілєв: Питання з контрактом на постачання електроенергії в Крим закрите", 2016). Prezydent Ukrainy P. Poroszenko poparł przedstawione wymogi i zgodził się, iż jeśli powyższe wymagania nie zostaną uwzględnione, to dostawy ener- 
gii elektrycznej na Krym nie będą wznowione („Крим у темряві: Чи довго протримається блокада?", 2015). Rosja nie przystała na ukraińskie wymogi i żadnych negocjacji na początku 2016 roku nie było. Jednocześnie kierownictwo okupowanego półwyspu powiedziało, iż krymskie społeczeństwo nie chce ukraińskiego prądu i aby to udowodnić, prezydent Rosji W. Putin inicjował "socjologiczne ankietowanie telefoniczne" z pytaniem, czy mieszkańcy półwyspu są zgodni, aby w nowym kontrakcie na dostawy prądu z Ukrainy Krym i Sewastopol wskazano jako część terytorium Ukrainy. Wyniki badan wskazały, iż 93,1\% mieszkańców Krymu opowiedziało się, iż są gotowi znosić przerwy w dostawach prądu w ciągu najbliższych 3-4 miesięcy („Експрес-опитування Путіна: 94\% кримчан готові жити без світла", 2016).

W odpowiedzi na rosyjskie ankiety, ukraińscy blogerzy również przeprowadzili własne badanie, wyniki którego pokazały, iż 58\% mieszkańców Krymu popiera podpisanie przez Rosję porozumienia z Ukrainą o dostawach energii elektrycznej z Ukrainy, przy czym oni także są zgodni, aby w dokumencie Krym był zaznaczony jako część terytorium Ukrainy. Jedynie 32\% ankietowanych powiedziało, iż są gotowi znosić przerwy w dostawach prądu („,Крымчане готовы признать Крым украинским в обмен на свет - новый опрос", 2016).

Podsumowując energetyczną blokadę Krymu, z pewnością można powiedzieć, iż była ona udana. Jak poinformowała wicepremier Krymu J. Bawykina, w związku z przerwaniem dostaw energii elektrycznej Krym poniósł znaczące straty - 12 mln dolarów. W szczególności straty poniosły przedsiębiorstwa przemysłowe - $900 \mathrm{mln}$ rubli, straty wojskowo-przemysłowego kompleksu Krymu zostały ocenione na $190 \mathrm{mln}$ rubli („В оккупированном Крыму подсчитывают убытки от энергоблокады”, 2016).

\section{BLOKADA MORSKA}

Kolejnym, trzecim, etapem blokady Krymu była zapowiedziana blokada morska. Miała ona rozpocząć się na początku 2016 roku. Celem tej akcji było, aby okupowany Krym "sprawiał jak najwięcej problemów okupantom" (Wesolowsky, 2016; "Активісти прогнозують початок морської блокади Криму на початку 2016", 2015). Do blokady morskiej aktywiści krymskotatarskiego ruchu narodowego podchodzą z ogromną odpowiedzialnością, jak powiedział przewodniczący Medżlisu Refat Czubarow, iż grupa prawników bada prawne zasady morskiej blokady Krymu. Ponadto przewodniczący Medżlisu powiedział, iż prawnicy badają doświadczenia międzynarodowych organizacji ds. praw człowieka, w szczególności, Greenpeace, działacze której wielokrotnie przeprowadzali akcje blokady okrętów, w tym akcję blokady rosyjskiego lodołamacza Arctic Sunrise („Чубаров розповів, яким чином активісти планують реалізувати морську блокаду Криму", 2015). Lider Tatarów krymskich Mustafa Dżemilew zauważył, iż całkowita morska blokada Krymu nie jest możliwa, gdyż do tego są potrzebne okręty wojenne. Takiej blokady mogą dokonać okręty NATO, gdyby zapadła taka decyzja. Co dotyczy morskiej blokady przez krymskotatarskich działaczy, to miała ona na celu kontrolę nad produkcją, która na barkach jest przemycana przez wody neutralne („Джемілєв вважає неможливою морську блокаду всього Криму", 2016). Na takich wodach statki, które wypływają z ukraińskich portów w innym kierunku, przekazują statkom rosyjskim towary, które później są dostarczane na okupowany przez Rosję Krym. 


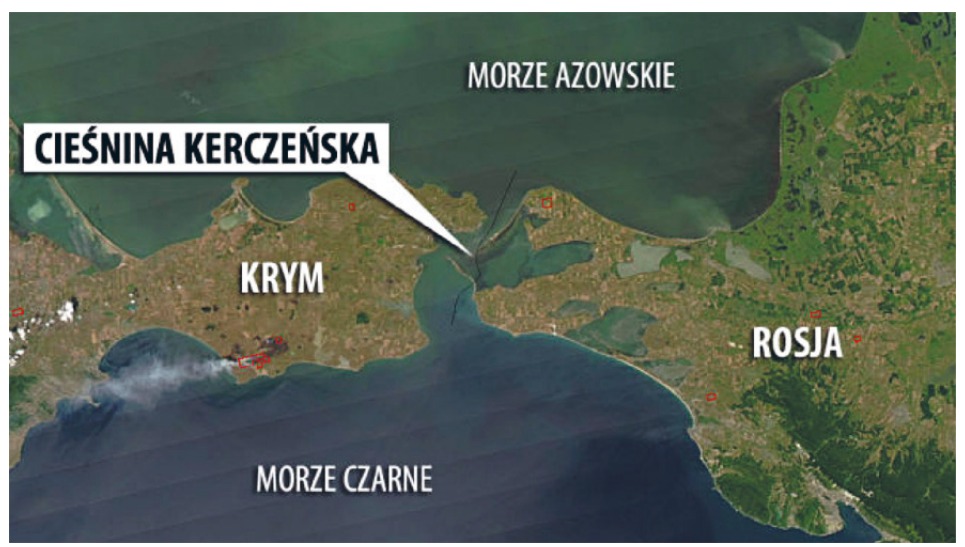

Ryc. 6.

Żród o: Grożą blokadą morską Krymu. „Aby pobyt okupanta na naszej ziemi był jak najdroższy" (2015).

Obecnie pomiędzy Krymem i Rosją istnieje połączenie promowe. Codziennie cztery promy osiem razy kursują pomiędzy brzegami Cieśniny Kerczeńskiej; są dwa sposoby, by ją zablokować: zaminowanie lub blokada okrętami wojennymi. Żadnej możliwości Ukraina nie posiada, a rosyjscy pogranicznicy są dobrze wyszkoleni i w razie blokady potrafią stawić opór. Próby blokady statków pasażerskich i handlowych za pomocą barek mogą na początku spowodować nieznaczne trudności w nawigacji, ale jednocześnie mogą spowodować zatonięcie barek i ofiary w ludziach na ich pokładzie. Poza tym, takie działania mogą być traktowane jako naruszenie podstawowych zasad międzynarodowego prawa morskiego oraz kodeksu karnego („Крым: Блокада с суши, блокада с моря. Фантазеры (патриоты) самоубийцы", 2015). Jedynym sposobem na morską blokadę Krymu są warunki pogodowe. W sezonie sztormów i niskich temperatur, które nawiedzają półwysep w okresie od grudnia po marzec, Cieśnina Kerczeńska stanowi niebezpieczeństwo dla nawigacji. Poza tym, w okresach bardzo niskich temperatur, Cieśnina zamarza, jak to miało miejsce w 2014 roku („Керченский пролив и Азовское море замерзли до самого горизонта", 2014).

Obecnie prowadzone są negocjacje, aby Unia Europejska nałożyła dodatkowe sankcje na Rosję za naruszenie ukraińskiej przestrzeni wodnej (wód terytorialnych). Naruszeniem prawa jest układanie kabli podwodnych na dnie Cieśniny Kerczeńskiej, budowa mostu samochodowego oraz budowa mostu drogowego bez zgody na to strony ukraińskiej, co według prawa międzynarodowego jest naruszeniem integralności terytorialnej Ukrainy („Джемилев: Морская блокада Крыма касается прежде всего Херсонской области“, 2015).

Podsumowując działania krymskotatarskich aktywistów dotyczące transportowej, towarowej i energetycznej blokady Krymu, można powiedzieć, iż mimo że nie udało się osiągnąć podstawowego celu tego przedsięwzięcia - uwolnienia wszystkich krymskich więźniów politycznych, akcja była udana. Przede wszystkim konsolidowała ona ukraińskie społeczeństwo, problem Krymu znów udało się podnieść do rangi międzynarodowej. Cena utrzymania Krymu przez Rosję również znacznie wzrosła, wstrzymanie dostaw wody (zależność w 86\%), żywności (zależność w 80\%), energii elektrycznej (zależność w $85 \%$ ) oraz połączenia transportowego (pociągi, statki, samoloty) znacznie uderzyła 
w rosyjski budżet, który w wyniku aneksji Krymu cierpi z powodu sankcji gospodarczych. Obecnie blokada Krymu przybiera inne formy, krymskotatarscy i ukraińscy aktywiści likwidują punkty postoju, których było sześć, i przenoszą się na przejścia graniczne, aby razem z pogranicznikami kontrolować porządek i zapobiegać naruszeniom ładu ( „Активісти блокади Криму знімають блокпости, - Іслямов", 2015). Poza tym co dotyczy blokady morskiej, Ukrainie w tym niespecjalnie pomaga Turcja, która blokuje rosyjskie okręty w Cieśninach Bosfor i Dardanele (Morgan, 2015; „Turcja blokuje rosyjskie okręty. Krążownik "Moskwa" obserwowany", 2015). Przyczyną blokady jest pogorszenie stosunków Ankara -Moskwa za sprawą zestrzelenia rosyjskiego bombowca przez siły tureckie, który naruszył przestrzeń powietrzną Turcji. W artykule The domestic logic of Ukraine's Crimea "blockade" dla European Council on Foreign Relations Gustaw Gressel bardzo sceptycznie odnosi się do blokady Krymu, gdyż uważa, że Rosja nie pójdzie na żadne negocjacje w sprawie Krymu i szansy na jego powrót są tylko po upadku reżimu Putina w Rosji (Gressel, 2015).

\section{BIBLIOGRAFIA}

48\% українців вважають, що потрібно проводити енергетичну блокаду Криму. (2016). Роbrano 3 lutego 2016, z https://tns-ua.com/news/48-ukrayintsiv-vvazhayut-shho-potribno -provoditi-energetichnu-blokadu-krimu

Gressel, G. (2015, grudzień 3). The domestic logic of Ukraine's Crimea "blockade". Pobrano 3 lutego 2016, z http://www.ecfr.eu/article/commentary_the_domestic_ logic_of_ukraines_crimea_blockade5042

Grożą blokadą morską Krymu. "Aby pobyt okupanta na naszej ziemi był jak najdroższy”. (2015, grudzień 16). Pobrano 3 lutego 2016, z http://www.tvn24.pl/wiadomosci-zeswiata,2/ukrainscy-aktywisci-zapowiadaja-blokade-morska-krymu,603490.html

Konwencja genewska o ochronie osób cywilnych podczas wojny (IV konwencja genewska), Genewa, 12 sierpnia 1949 r. (b.d.). In Dz. U z 1956r., nr 38, poz. 171, załącznik. Pobrano 1 kwietnia 2016, z https://mswia.gov.pl/ftp/OCK/dokumenty_Prawo_ MPH/1949_12_VIII_IV\%20konwencja_genewska.pdf

Крим буде потерпати від перебоїв з електроенергією до 2018 року - Аксьонов. (2015, grudzień 2). Pobrano 3 lutego 2016, z http://dt.ua/UKRAINE/krim-bude-poterpati-vid-pereboyiv-z-elektroenergiyeyu-do-2018-roku-aksonov-192786_.html

Morgan, W. (2015, grudzień 18). Russia-Turkey crisis: 27 Russian ships blocked after Moscow detains Turkish vessels amid escalating tensions. Pobrano 3 lutego 2016, z http://www.ibtimes.com/russia-turkey-crisis-27-russian-ships-blocked-after-moscow-detains-turkishvessels-2231946

Stewart, P. H. (2015, grudzień 15). Life in the shadows of the Crimea blockade. Pobrano 3 lutego 2016, z http://www.aljazeera.com/indepth/features/2015/12/life-shadows-crimea-blockade-151214100451133.html

Turcja blokuje rosyjskie okręty. Krążownik "Moskwa” obserwowany. (2015, listopad 30). Pobrano 3 lutego 2016, z http://www.tvp.info/22864663/turcja-blokuje-rosyjskie-okrety -krazownik-moskwa-obserwowany

Wesolowsky, T. (2016, styczeń 19). Tatar leader vows Crimea blockade will continue. Pobrano 3 lutego 2016, z http://www.rferl.org/content/ukraine-crimea-blockade-tatarleader-vosw-continue/27497515.html 
Азов присоединился к блокаде крыма. (2015, październik 1). Pobrano 3 lutego 2016, z http://korrespondent.net/ukraine/3570663-azov-prysoedynylsia-k-blokade-kryma

Активісти блокади Криму знімають блокпости, - Іслямов. (2015, grudzień 31). Pobrano 3 lutego 2016, z http://espreso.tv/news/2015/12/31/aktyvisty_blokady_krymu_znimayut_ blokposty_islyamov

Активісти прогнозують початок морської блокади Криму на початку 2016. (2015, grudzień 16). Pobrano 3 lutego 2016, z http://dt.ua/UKRAINE/aktivisti-prognozuyut-pochatokmorskoyi-blokadi-krimu-na-pochatku-2016-194194_.html

В Криму ввели надзвичайний стан. (2015, listopad 22). Pobrano 3 lutego 2016, z http://24tv. ua/v_krimu_vveli_nadzvichayniy_stan_n633147

В оккупированном Крыму подсчитывают убытки от энергоблокады. (2016, styczeń 10). Pobrano 3 lutego 2016, z http://hvylya.net/news/digest/v-okkupirovannom-kryimu-podschityivayut-ubyitki-ot-energoblokadyi.html

Відключити, щоб дати. „Дивна” блокада Криму. (2015, grudzień 9). Pobrano 3 lutego 2016, z http://ua.korrespondent.net/ukraine/3600818-vidkluichyty-schob-daty-dyvna-blokadakrymu

Дві третини газу в Україну надходить з ЄС, і лише третина - з Pociї. (2015, listopad 2). Pobrano 3 lutego 2016, z http://dt.ua/ECONOMICS/dvi-tretini-gazu-v-ukrayinu-nadhodit-z-yesi-lishe-tretina-z-rosiyi-189777_.html

Джемилев: Будем менять товары для Крыма на наших заключенных. (2015, wrzesień 24). Pobrano 3 lutego 2016, z http://ru.krymr.com/content/news/27267137.html

Джемилев: Морская блокада Крыма касается прежде всего Херсонской области. (2015, grudzień 9). Pobrano 3 lutego 2016, z http://www. blackseanews.net/read/109359

Джемілєв вважає неможливою морську блокаду всього Криму. (2016, styczeń 2). Pobrano 3 lutego 2016, z http://dt.ua/UKRAINE/dzhemilyev-vvazhaye-nemozhlivoyu-morsku-blokadu-vsogo-krimu-195708_.html

Джемілєв назвав причини відновлення Україною електропостачання в Криму. (2015, grudzień 14). Pobrano 3 lutego 2016, z http://ua.racurs.ua/news/62741-djemiliev-nazvavprychyny-vidnovlennya-ukrayinou-elektropostachannya-v-krymu?_ga=1.76696657.514 374349.1437568719

Джемілєв: Питання з контрактом на постачання електроенергії в Крим закрите. (2016, styczeń 12). Pobrano 4 lutego 2016, z http://zik.ua/news/2016/01/12/dzhemiliev_ pytannya_z_kontraktom_na_postachannya_elektroenergii_v_krym_661908

Експрес-опитування Путіна: 94\% кримчан готові жити без світла. (2016, styczeń 1). Pobrano 4 lutego 2016, z http://qha.com.ua/ua/politika/ekspresopituvannya-putina-94-krimchangotovi-jiti-bez-svitla/2633/

Імпорт природного газу в Україну у 2008-2014 рр. (2016, styczeń 22). Pobrano 3 lutego 2016, z http://naftogaz-europe.com/article/ua/NaturalGasSuppliestoUkraine

Іслямов пояснив ослаблення енергоблокади Криму тиском Заходу. (2015, grudzień 7). Pobrano 3 lutego 2016, z http://dt.ua/ECONOMICS/islyamov-poyasniv-oslablennya-energoblokadi-krimu-tiskom-zahodu-193343_html

Керченский пролив и Азовское море замерзли до самого горизонта. (2014, luty 3). Pobrano 3 lutego 2016, z http://www.sobytiya.info/photos/14/38202

Крим на підсосі: Чому енергоміст Кубань - Крим не розв'яже проблем півострова. (2015, grudzień 16). Pobrano 4 lutego 2016, z http://forbes.ua/ua/nation/1407611-krim-na-pidsosi-chomu-energomist-kuban-krim-ne-rozv-yazhe-problem-pivostrova 
Крим у темряві: Чи довго протримається блокада? (2015, listopad 15). Pobrano 3 lutego 2016, z http://www.bbc.com/ukrainian/politics/2015/11/151123_crimea_electricity_vc

Крым будет зависеть от украинской электроэнергии минимум до 2018 года. (2015, grudzień 2). Pobrano 3 lutego 2016, z http://rus.newsru.ua/ukraine/02dec2015/krym2018.html

Крым: Блокада с суши, блокада с моря. Фантазеры (патриоты) самоубийцы. (2015, grudzień 2). Pobrano 3 lutego 2016, z http://rian.com.ua/columnist/20151202/1001338579.html

Крымская блокада: Итоги первой недели. (2015, Wrzesień 28). Pobrano 4 lutego 2016, z http://ru.krymr.com/content/article/27275650.html

Крымчане готовы признать Крым украинским в обмен на свет - новый опрос. (2016, styczeń 4). Pobrano 4 lutego 2016, z http://uapress.info/ru/news/print/112641

Лише 25\% українців виступають проти енергетичної блокади окупованого Криму. (2015, listopad 19). Pobrano 3 lutego 2016, z http://dt.ua/UKRAINE/lishe-25-ukrayinciv-vistupayut-proti-energetichnoyi-blokadi-okupovanogo-krimu-191534_.html

Месть за блокаду. Меджлис в Крыму приравнивают к «Правому сектору». (2015, wrzesień 24). Pobrano 3 lutego 2016, z http://ru.krymr.com/content/article/27268366.html

Мустафа Джемилев: Коренной народ Крыма - организованная сила, оказывающая сопротивление оккупации в общенациональном масштабе. (2015, październik 18). Pobrano 4 lutego 2016, z http://ru.krymr.com/content/article/27291551.html06.10.2015

На Херсонщині пошкодили опору ЛЕП, що постачає електрику в Крим. (2016, styczeń 22). Pobrano 4 lutego 2016, z http://www.pravda.com.ua/news/2015/10/6/7083835/

Нафтогаз припускає повну відмову від газу Газпрому з 2016 року. (2015, październik 29). Pobrano 3 lutego 2016, z http://dt.ua/ECONOMICS/naftogaz-pripuskaye-povnu-vidmovavid-gazu-gazpromu-z-2016-roku-189326_.html

Опубликована инфографика следствий блокады Крыма. (2015, wrzesień 23). Pobrano 3 lutego 2016, z http://bykvu.com/home/bukvy/9097/opublikovana-infografika-posledstvijblokady-kryma.html

Офіційна заява штабу акції „Громадська блокада Криму”. Крим - це Україна! Без Криму немає України! (2015, wrzesień 22). Pobrano 4 lutego 2016, z https://www.facebook. com/atr.channel/posts/1010816772272891

Перекриті дороги та довжелезні черги з фур. Як почалася блокада Криму. (2015, wrzesień 20). Pobrano 3 lutego 2016, z http://tsn.ua/ukrayina/perekriti-dorogi-ta-dovzhelezni -chergi-z-fur-yak-pochalasya-blokada-krimu-497020.html

По всьому Криму відновили енергопостачання. (2015, grudzień 10). Pobrano 3 lutego 2016, z http://zik.ua/news/2015/12/10/po_vsomu_krymu_vidnovyly_energopostachannуa_652739

Половина українців схвалили блокаду Криму активістами, третина - проти. (2016, styczeń 13). Pobrano 3 lutego 2016, z http://dt.ua/UKRAINE/polovina-ukrayinciv-shvaliliblokadu-krimu-aktivistami-tretina-proti-196502_.html

Потрійна енергетична залежність України. (2014, listopad 26). Pobrano 3 lutego 2016, z http://energy.apostrophe.com.ua/enerhetychnyy-rynok/novyny/analityka/potriynaenerhetychna-zalezhnist-ukrayiny/

Правий сектор припиняє участь у торгівельній та енергетичній блокаді Криму. (2015, grudzień 8). Pobrano 3 lutego 2016, z http://www.dw.com/uk/правий-сектор-припиняєучасть-у-торгівельній-та-енергетичній-блокаді-криму/а-18901156

Про обмеження поставок окремих товарів (робіт, послуг) з тимчасово окупованої території на іншу територію України та/або з іншої території України на тимчасово окуповану територію. Постанова від 16 грудня 2015 р. № 1035. (2015). Pobrano 3 lutego 2016, z http://www.kmu.gov.ua/control/uk/cardnpd?docid=248714822 
Путілов, І. (2015, październik 2). Битва біля «Титану». Чи переживе блокаду Криму завод Фірташа? Pobrano 3 lutego 2016, z http://ua.krymr.com/content/article/27283054.html

Путін зізнався, що „увімкнув” Крим не дуже вдало. (2016, styczeń 22). Pobrano 3 lutego 2016, z http://www.depo.ua/ukr/life/putin-ziznavsya-shcho-uvimknuv-krim-ne-duzhevdalo-02122015222600

Росія розмістила танки та „Гради” біля лінії розмежування між Кримом і Херсонщиною через підрив ЛЕП - Ківа. (2015, listopad 23). Pobrano 3 lutego 2016, z http://www.unian.ua/ society/1191059-rosiya-rozmistila-tanki-bilya-liniji-rozmejuvannya-mij-krimom-i-hersonschinoyu-cherez-pidriv-lep-kiva.html

Российские спецслужбы пытаются дискредитировать блокаду Крыма - Госпогранслужба Украины. (2015, październik 2). Pobrano 3 lutego 2016, z http://ru.krymr.com/content/ news/27283201.html

Россия намерена поднимать вопрос блокады Крыма в международных организациях. (2015, wrzesień 23). Pobrano 3 lutego 2016, z http://ru.krymr.com/content/news/27264439. html

Самар, В. (2015a, grudzień 11). Заземлення агресора. Pobrano 3 lutego 2016, z http://gazeta.dt.ua/internal/zazemlennya-agresora-_.html

Самар, В. (2015b, wrzesień 11). Зона особливої неуваги. Pobrano 3 lutego 2016, z http:// gazeta.dt.ua/internal/zona-osoblivoyi-neuvagi-_.html

Семь вопросов и ответов о блокаде Крыма. (2015, wrzesień 23). Pobrano 3 lutego 2016, z http://ru.krymr.com/content/article/27264702.html

Сергеева, Е. (2015, wrzesień 25). Субъекты и объекты крымской блокады. (2015). Pobrano 3 lutego 2016, z http://ru.krymr.mobi/a/27268450.html

У Раді зареєстрували законопроект про скасування вільної економічної зони «Крим». (2015, listopad 4). Pobrano 3 lutego 2016, z http://www.radiosvoboda.org/content/ news/27345056.html

Украина отторгает Крым. Сама. (2015, wrzesień 25). Новая газета. Pobrano 3 lutego 2016, z http://www.novayagazeta.ru/politics/70070.html

Украина продолжает снабжать сырьем завод «Титан» в оккупированном Крыму. (2015, styczeń 25). Pobrano 3 lutego 2016, z http://www.blackseanews.net/read/111401

Україна скоротила імпорт газу у 2015 році на 16\%. (2016, styczeń 6). Pobrano 3 lutego 2016, z http://dt.ua/ECONOMICS/na-1-sichnya-2016-roku-ukrayina-domoglasya-skorochennya-importu-gazu-na-16-195963_.html

чубаров подробно огласил причины и цели блокады Крыма. (2015, wrzesień 23). Pobrano 3 lutego 2016, z http://bykvu.com/home/bukvy/9122.html

Чубаров розповів, яким чином активісти планують реалізувати морську блокаду Криму. (2015, grudzień 4). Pobrano 3 lutego 2016, z http://nv.ua/ukr/ukraine/politics/chubarovrozpoviv-jak-aktivisti-planujut-realizuvati-morsku-blokadu-krimu-83943.html

Чубаров: «Энергетическая блокада» Крыма может начаться в октябре. (2015, wrzesień 22). Pobrano 3 lutego 2016, z http://ru.krymr.com/content/news/27263044.html

Чубаров: Блокада полуострова возвращает проблему Крыма в первый ряд. (2015, wrzesień 23). Pobrano 4 lutego 2016, z http://ru.krymr.com/content/news/27264079.html 
48\% ukraïntsiv vvazhaiut', shcho potribno provodyty enerhetychnu blokadu Krymu. (2016). Retrieved 3 February 2016, from https://tns-ua.com/news/48-ukrayintsiv-vvazhayut-shho-potribno-provoditi-energetichnu-blokadu-krimu

Aktyvisty blokady Krymu znimaiut' blokposty, - Isliamov. (2015, December 31). Retrieved 3 February 2016, from http://espreso.tv/news/2015/12/31/aktyvisty_blokady_krymu_ znimayut_blokposty_islyamov

Aktyvisty prohnozuiut' pochatok mors'koï blokady Krymu na pochatku 2016. (2015, December 16). Retrieved 3 February 2016, from http://dt.ua/UKRAINE/aktivisti-prognozuyut-pochatok-morskoyi-blokadi-krimu-na-pochatku-2016-194194_.html

Azov prisoedinilsia k blokade Kryma. (2015, October 1). Retrieved 3 February 2016, from http://korrespondent.net/ukraine/3570663-azov-prysoedynylsia-k-blokade-kryma

Chubarov podrobno oglasil prichiny i tseli blokady Kryma. (2015, September 23). Retrieved 3 February 2016, from http://bykvu.com/home/bukvy/9122.html

Chubarov rozpoviv, iakym chynom aktyvisty planuiut' realizuvaty mors'ku blokadu Krymu. (2015, December 4). Retrieved 3 February 2016, from http://nv.ua/ukr/ukraine/politics/ chubarov-rozpoviv-jak-aktivisti-planujut-realizuvati-morsku-blokadu-krimu-83943.html

Chubarov: "Ėnergeticheskaia blokada» Kryma mozhet nachat'sia v oktiabre. (2015, September 22). Retrieved 3 February 2016, from http://ru.krymr.com/content/ news/27263044.html

Chubarov: Blokada poluostrova vozvrashchaet problemu Kryma v pervyī riad. (2015, September 23). Retrieved 4 February 2016, from http://ru.krymr.com/content/ news/27264079.html

Dvi tretyny hazu v Ukraïnu nadkhodyt' z IES, i lyshe tretyna - z Rosiï. (2015, November 2). Retrieved 3 February 2016, from http://dt.ua/ECONOMICS/dvi-tretini-gazu-v-ukrayinunadhodit-z-yes-i-lishe-tretina-z-rosiyi-189777_.html

Dzhemilev: Budem meniat' tovary dlia Kryma na nashikh zakliuchennykh. (2015, September 24). Retrieved 3 February 2016, from http://ru.krymr.com/content/news/27267137. html

Dzhemilev: Morskaia blokada Kryma kasaetsia prezhde vsego Khersonskol oblasti. (2015, December 9). Retrieved 3 February 2016, from http://www.blackseanews.net/ $\mathrm{read} / 109359$

Dzhemiliev nazvav prychyny vidnovlennia Ukraïnoiu elektropostachannia v Krymu. (2015, December 14). Retrieved 3 February 2016, from http://ua.racurs.ua/news/62741-djemiliev-nazvav-prychyny-vidnovlennya-ukrayinou-elektropostachannya-v-krymu?_ga=1.766 96657.514374349.1437568719

Dzhemiliev vvazhaie nemozhlyvoiu mors'ku blokadu vs'oho Krymu. (2016, styczeń 2). Retrieved 3 February 2016, from http://dt.ua/UKRAINE/dzhemilyev-vvazhaye-nemozhlivoyu-morsku-blokadu-vsogo-krimu-195708_.html

Dzhemiliev: Pytannia z kontraktom na postachannia elektroenerhiï v Krym zakryte. (2016, January 12). Retrieved 4 February 2016, from http://zik.ua/news/2016/01/12/dzhemiliev_pytannya_z_kontraktom_na_postachannya_elektroenergii_v_krym_661908

Ekspres-opytuvannia Putina: 94\% krymchan hotovi zhyty bez svitla. (2016, January 1). Retrieved 4 February 2016, from http://qha.com.ua/ua/politika/ekspresopituvannya-putina94-krimchan-gotovi-jiti-bez-svitla/2633/ 
Gressel, G. (2015, December 3). The domestic logic of Ukraine's Crimea "blockade". Retrieved 3 February 2016, from http://www.ecfr.eu/article/commentary_the_domestic_logic_of_ukraines_crimea_blockade5042

Grożą blokadą morską Krymu. „Aby pobyt okupanta na naszej ziemi był jak najdroższy”. (2015, December 16). Retrieved 3 February 2016, from http://www.tvn24.pl/wiadomosci-ze-swiata,2/ukrainscy-aktywisci-zapowiadaja-blokade-morska-krymu,603490.html Import pryrodnoho hazu v Ukraïnu u 2008-2014 rr. (2016, January 22). Retrieved 3 February 2016, from http://naftogaz-europe.com/article/ua/NaturalGasSuppliestoUkraine

Isliamov poiasnyv oslablennia enerhoblokady Krymu tyskom Zakhodu. (2015, December 7). Retrieved 3 February 2016, from http://dt.ua/ECONOMICS/islyamov-poyasnivoslablennya-energoblokadi-krimu-tiskom-zahodu-193343_.html

Kerchenskï proliv i Azovskoe more zamerzli do samogo gorizonta. (2014, February 3). Retrieved 3 February 2016, from http://www.sobytiya.info/photos/14/38202

Konwencja genewska o ochronie osób cywilnych podczas wojny (IV konwencja genewska), Genewa, 12 sierpnia 1949 r. (b.d.). In Dz. U. z 1956 r., nr 38, poz. 171, załącznik. Retrieved 1 April 2016, from https://mswia.gov.pl/ftp/OCK/dokumenty_Prawo_ MPH/1949_12_VIII_IV\%20konwencja_genewska.pdf

Krym bude poterpaty vid pereboïv z elektroenerhiieiu do 2018 roku - Aks'onov. (2015, December 2). Retrieved 3 February 2016, from http://dt.ua/UKRAINE/krim-bude-poterpati-vid-pereboyiv-z-elektroenergiyeyu-do-2018-roku-aksonov-192786_html

Krym budet zaviset' ot ukrainskol̆ èlektroènergii minimum do 2018 goda. (2015, December 2). Retrieved 3 February 2016, from http://rus.newsru.ua/ukraine/02dec2015/ krym2018.html

Krym na pidsosi: Chomu enerhomist Kuban' - Krym ne rozv'iazhe problem pivostrova. (2015, December 16). Retrieved 4 February 2016, from http://forbes.ua/ua/ nation/1407611-krim-na-pidsosi-chomu-energomist-kuban-krim-ne-rozv-yazhe-problempivostrova

Krym u temriavi: Chy dovho protrymaiet'sia blokada? (2015, November 15). Retrieved 3 February 2016, from http://www.bbc.com/ukrainian/politics/2015/11/151123_crimea_electricity_vc

Krym: Blokada s sushi, blokada s moria. Fantazery (patrioty) samoubiïtsy. (2015, December 2). Retrieved 3 February 2016, from http://rian.com.ua/columnist/20151202/ 1001338579.html

Krymchane gotovy priznat' Krym ukrainskim v obmen na svet - novyĭ opros. (2016, January 4). Retrieved 4 February 2016, from http://uapress.info/ru/news/print/112641

Krymskaia blokada: Itogi pervoĭ nedeli. (2015, September 28). Retrieved 4 February 2016, from http://ru.krymr.com/content/article/27275650.html

Lyshe 25\% ukraïntsiv vystupaiut' proty enerhetychnoï blokady okupovanoho Krymu. (2015, November 19). Retrieved 3 February 2016, from http://dt.ua/UKRAINE/lishe-25ukrayinciv-vistupayut-proti-energetichnoyi-blokadi-okupovanogo-krimu-191534_html

Mest' za blokadu. Medzhlis v Krymu priravnivaiut k "Pravomu sektoru». (2015, September 24). Retrieved 3 February 2016, from http://ru.krymr.com/content/article/ 27268366.html

Morgan, W. (2015, December 18). Russia-Turkey crisis: 27 Russian ships blocked after Moscow detains Turkish vessels amid escalating tensions. Retrieved 3 February 2016, from http://www.ibtimes.com/russia-turkey-crisis-27-russian-ships-blocked-after-moscowdetains-turkish-vessels-2231946 
Mustafa Dzhemilev: Korennoi narod Kryma - organizovannaia sila, okazyvaiushchaia soprotivlenie okkupatsii v obshchenatsional'nom masshtabe. (2015, October 18). Retrieved 4 February 2016, from http://ru.krymr.com/content/article/27291551.html06.10.2015

$\mathrm{Na}$ Khersonshchyni poshkodyly oporu LEP, shcho postachaie elektryku $\vee$ Krym. (2016, January 22). Retrieved 4 February 2016, from http://www.pravda.com.ua/news/ 2015/10/6/7083835/

Naftohaz prypuskaie povnu vidmovu vid hazu Hazpromu z 2016 roku. (2015, October 29). Retrieved 3 February 2016, from http://dt.ua/ECONOMICS/naftogaz-pripuskaye-povnuvidmova-vid-gazu-gazpromu-z-2016-roku-189326_.html

Ofitsiïna zaiava shtabu aktsiï "Hromads'ka blokada Krymu”. Krym - tse Ukraïna! Bez Krymu nemaie Ukraïny! (2015, September 22). Retrieved 4 February 2016, from https://www.facebook.com/atr.channel/posts/1010816772272891

Opublikovana infografika sledstvii blokady Kryma. (2015, September 23). Retrieved 3 February 2016, from http://bykvu.com/home/bukvy/9097/opublikovana-infografika-posledstvij-blokady-kryma.html

Perekryti dorohy ta dovzhelezni cherhy z fur. IAk pochalasia blokada Krymu. (2015, September 20). Retrieved 3 February 2016, from http://tsn.ua/ukrayina/perekriti-dorogi-tadovzhelezni-chergi-z-fur-yak-pochalasya-blokada-krimu-497020.html

Po vs'omu Krymu vidnovyly enerhopostachannia. (2015, December 10). Retrieved 3 February 2016, from http://zik.ua/news/2015/12/10/po_vsomu_krymu_vidnovyly_ energopostachannya_652739

Polovyna ukraïntsiv skhvalyly blokadu Krymu aktyvistamy, tretyna - proty. (2016, January 13). Retrieved 3 February 2016, from http://dt.ua/UKRAINE/polovina-ukrayinciv-shvaliliblokadu-krimu-aktivistami-tretina-proti-196502_.html

Potriïna enerhetychna zalezhnist' Ukraïny. (2014, November 26). Retrieved 3 February 2016, from http://energy.apostrophe.com.ua/enerhetychnyy-rynok/novyny/analityka/ potriyna-enerhetychna-zalezhnist-ukrayiny/

Pravyi sektor prypyniaie uchast' u torhivel'nii ta enerhetychnii blokadi Krymu. (2015, December 8). Retrieved 3 February 2016, from http://www.dw.com/uk/правий-секторприпиняє-участь-у-торгівельній-та-енергетичній-блокаді-криму/а-18901156

Pro obmezhennia postavok okremykh tovariv (robit, posluh) z tymchasovo okupovanoï terytoriï na inshu terytoriiu Ukraïny ta/abo z inshoï terytoriï Ukraïny na tymchasovo okupovanu terytoriiu. Postanova vid 16 hrudnia 2015 r. No 1035. (2015). Retrieved $3 \mathrm{Fe}-$ bruary 2016, from http://www.kmu.gov.ua/control/uk/cardnpd?docid=248714822

Putilov, I. (2015, October 2). Bytva bilia "Tytanu». Chy perezhyve blokadu Krymu zavod Firtasha? Retrieved 3 February 2016, from http://ua.krymr.com/content/article/ 27283054.html

Putin ziznavsia, shcho „uvimknuv" Krym ne duzhe vdalo. (2016, January 22). Retrieved 3 February 2016, from http://www.depo.ua/ukr/life/putin-ziznavsya-shcho-uvimknuvkrim-ne-duzhe-vdalo-02122015222600

Rosiia rozmistyla tanky ta „Hrady“ bilia liniï rozmezhuvannia mizh Krymom i Khersonshchynoiu cherez pidryv LEP - Kiva. (2015, November 23). Retrieved 3 February 2016, from http://www.unian.ua/society/1191059-rosiya-rozmistila-tanki-bilya-liniji-rozmejuvannya-mij-krimom-i-hersonschinoyu-cherez-pidriv-lep-kiva.html

Rossiia namerena podnimat' vopros blokady Kryma $v$ mezhdunarodnykh organizatsiiakh. (2015, September 23). Retrieved 3 February 2016, from http://ru.krymr.com/content/ news/27264439.html 
Rossiïskie spetssluzhby pytaiutsia diskreditirovat' blokadu Kryma - Gospogransluzhba Ukrainy. (2015, October 2). Retrieved 3 February 2016, from http://ru.krymr.com/content/news/27283201.html

Samar, V. (2015a, December 11). Zazemlennia ahresora. Retrieved 3 February 2016, from http://gazeta.dt.ua/internal/zazemlennya-agresora-_.html

Samar, V. (2015b, September 11). Zona osoblyvoï neuvahy. Retrieved 3 February 2016, from http://gazeta.dt.ua/internal/zona-osoblivoyi-neuvagi-_.html

Sem' voprosov i otvetov o blokade Kryma. (2015, September 23). Retrieved 3 February 2016, from http://ru.krymr.com/content/article/27264702.html

Sergeeva, E. (2015, September 25). Sub"ekty i ob"ekty krymskoĭ blokady. (2015). Retrieved 3 February 2016, from http://ru.krymr.mobi/a/27268450.html

Stewart, P. H. (2015, December 15). Life in the shadows of the Crimea blockade. Retrieved 3 February 2016, from http://www.aljazeera.com/indepth/features/2015/12/lifeshadows-crimea-blockade-151214100451133.html

Turcja blokuje rosyjskie okręty. Krążownik „Moskwa” obserwowany. (2015, November 30). Retrieved 3 February 2016, from http://www.tvp.info/22864663/turcja-blokuje-rosyjskie-okrety-krazownik-moskwa-obserwowany

U Radi zareiestruvaly zakonoproekt pro skasuvannia vil'noï ekonomichnoï zony "Krym». (2015, November 4). Retrieved 3 February 2016, from http://www.radiosvoboda.org/ content/news/27345056.html

Ukraina ottorgaet Krym. Sama. (2015, September 25). Novaia gazeta. Retrieved 3 February 2016, from http://www.novayagazeta.ru/politics/70070.html

Ukraina prodolzhaet snabzhat' syr'em zavod "Tytan» v okkupirovannom Krymu. (2015, January 25). Retrieved 3 February 2016, from http://www.blackseanews.net/read/ 111401

Ukraïna skorotyla import hazu u 2015 rotsi na 16\%. (2016, January 6). Retrieved 3 February 2016, from http://dt.ua/ECONOMICS/na-1-sichnya-2016-roku-ukrayina-domoglasyaskorochennya-importu-gazu-na-16-195963_.html

V Krymu vvely nadzvychaïnyĭ stan. (2015, November 22). Retrieved 3 February 2016, from http://24tv.ua/v_krimu_vveli_nadzvichayniy_stan_n633147

V okkupirovannom Krymu podschityvaiut ubytki ot ènergoblokady. (2016, January 10). Retrieved 3 February 2016, from http://hvylya.net/news/digest/v-okkupirovannom-kryimupodschityivayut-ubyitki-ot-energoblokadyi.html

Vidkliuchyty, shchob daty. „Dyvna” blokada Krymu. (2015, December 9). Retrieved 3 February 2016, from http://ua.korrespondent.net/ukraine/3600818-vidkluichyty-schob-daty-dyvna-blokada-krymu

Wesolowsky, T. (2016, January 19). Tatar leader vows Crimea blockade will continue. Retrieved 3 February 2016, from http://www.rferl.org/content/ukraine-crimea-blockadetatar-leader-vosw-continue/27497515.html 